Ольга Говоровська,

доктор історичних наук, професор

кафедри менеджменту освіти та практичної психологї̈, ДВНЗ «ПереяславХмельнииький державний педагогічний університет імені Григорія Сковороди».

E-mail: olka-elka@ukr.net

ORCID 0000-0002-8580-8839

\title{
ВПЛИВ СУСПІЛЬНИХ ЗАПИТІВ НА ПОЯВУ ТА РОЗВИТОК СИСТЕМ УПРАВЛІННЯ ЯКІСТЮ ВИЩОЇ ОСВІТИ У ХХ-ХХІ СТ.
}

У статті розглядаються деякі аспекти виникнення сучасних систем управління якістю освіти. Визначається місие та роль системи вищої освіти в державі, рівень вимог та тенденції розбудови інформаційного суспільства на початку ХХ століття.

Розглядається вклад американського аналітика У. Шухарта, який заснував методику статистичного аналізу виробничого процесу та виявлення браку на виробництві, які згодом були названі карти Шухарта.

Також, приділяється увага теорії якості Е. Демінга, який зробив величезний вплив на відродження післявоєнної Японії $і$ США у 80-х роках. Теорії Джозефа М. Джурана - автора «Довідника по управлінню якістю» (Handbook for Quality Control), від якої веде свій початок поняття «керування якістю». Розглядаються роботи Ісікави, як автора японського варіанту комплексного управління якістю. Геніті Taгуmi (Genichi Taguchi, нар. в 1924p.) - відомий японський статистик, розвинув ідеї математичної статистики планування експерименту і контролю якості. У статті розглядаємо визначення підходу TQM та МС ICO 9004:2000: вимоги, які вони містять до запитів споживачів. Порівнюються основні критерії якості вищої освіти, за визначенями Свропейської асочіаџї̈ ENQA (European Network for Quality Assurance) ma UNESCO-CEPES.

Ключові слова: якість вищої освіти, історія розвитку критерї̈в якості, статичний аналіз, TQM, MC ICO 9004:2000, ENQA, UNESCO-CEPES.

In the article we discuss about the aspects of the emergence of modern quality education management systems are considered in the article. The place and role of the higher education system in the state, the level of requirements and trends of the development of the information society in the beginning of the $X X$ century are determined.

Over the past decades, the development of the information society in Ukraine and the introduction of stateof-the-art information and communication technologies in all spheres of public life, as well as in the activities of state authorities and local self-government bodies is one of the priority directions of state policy both at present and in the future. The level of requirements put forward by the state prior to the training of qualified specialists is constantly changing and growing. This tendency is connected with the constant world development of the information society in the world, as well as the constant growth of the influence of the field of information and communication technologies on all levels of our lives. The contribution of the American analyst U. Shuhart, which is based on the method of statistical analysis of the production process and the identification of production shortages, which were subsequently named Shuhart cards, are considered.

Also, attention is paid to the quality theory of E. Dieming, which had a huge impact on the revival of postwar Japan and the United States in the 80's. Theories of Joseph M.Juran are the author of the "Handbook for Quality Control", from which the concept of "quality management" has its origin. The work of Ishikawa, as the author of the Japanese version of integrated quality management, is considered. Geniti Taguchi (Genichi Taguchi, born in 1924) a well-known Japanese statistician, developed the ideas of mathematical statistics for experiment planning and quality control. In the article, we consider the definition of the TQM and MS ISO 9004: 2000 approach: the requirements they contain to consumer inquiries. The main criteria for the quality of higher education are compared, as defined by the European Association for Quality Assurance (ENQA) and UNESCO-CEPES.

Keywords: higher education quality, history of development of quality criteria, static analysis, TQM, MS ISO 9004: 2000, ENQA, UNESCO-CEPES. 
Постановка проблеми. Упродовж останніх десятиріч розвиток інформаційного суспільства в Україні та впровадження новітніх інформаційнокомунікаційних технологій в усі сфери суспільного життя, а також в діяльність органів державної влади та органів місцевого самоврядування $\epsilon$ одним 3 пріоритетних напрямів державної політики як на теперішній час так i на перспективу. Рівень вимог, які висуває держава до підготовки якісних фахівців постійно змінюється і зростає. Така тенденція пов'язана 3 постійною світовою розбудовою інформаційного суспільства в світі, а також постійним зростанням впливу.

Місце, яке відводиться вищій освіті, визначає для неї роль провідного центру. Більш того, роль університету, як гаранта академічного порядку i стабільності може стати навіть ще важливішою. Вже сьогодні, він повинен взаємодіяти з освітніми та іншими установами, поступово збільшуючи відкритість системи. Тому, на сьогоднішній день, велика увага приділяється підвищенню якості вищої освіти, як основному показнику передачі накопичених знань, виховання творчого підходу, моральних якостей, внутрішньої культури, здатності сприймати і брати активну участь у постійних змінах та самовдосконаленні.

Стратегічно важливим стає підготовка високопрофесійних кадрів, здатних розвивати інформаційно-комунікаційні технології і ефективно використовувати їх на практиці. Звичайно, для успішного вирішення цієї задачі, в першу чергу, необхідне наукове забезпечення i практичне впровадження в національну систему освіти цілісної концепції запровадження інформаційно-комп'ютерних технологій, у відповідності з міжнародними вимогами до освітніх стандартів і високоефективних системоутворюючих механізмів і технологій.

Аналіз останніх досліджень $\boldsymbol{i}$ публікацій. Значна увага питанням якості вищої освіти в приділялась в роботах В. Журавського, А. Загороднього, С. Ніколаєнко, В. Андрущенко, І. Жовтої, Г. Клімової, соціологічних дослідженнях В. Кушерець, М. Романенко, Н. Щипачова, з боку інформаційно-комунікаційних технологій М. Скиба, М. Семекін, економічного зростання - Дж. Мілль, А. Егоришин, Е. Шиндовський. Також, варто відзначити В. Стритинга, Г. Вайза, П. Тейлора та Е. Данн. Проблему порівняльного аналізу якості вищої освіти досліджували Г. Калінічева, Н. Статінова, Н. Сухова, О. Ворожейкіна.

Mema cmammi - розкрити аспекти впливу суспільних запитів на появу та розвиток систем управління якістю вищої освіти у XX-XXI ст.

Виклад основного матеріалу. Для поступового розвитку освітньої системи України важливо розглядати поняття «якість», не лише зі сторони показника відповідальності закладів вищої освіти, а також, зі сторони чіткого розуміння, що вона не може повноцінно та ефективно реалізовуватись без підтримки загального забезпечення та дотримання у всіх сферах життя. Враховуючи що розвиток систем управління якістю освіти, як науки, має не таку довгу історію, метою статті буде розглянути деякі історичні аспекти які сприяли формуванню «якості», «якості освіти», а також їх основним критеріям визначення і показникам.

На початку використання, поняття «якість» включало в себе традиційний економічний показник для оцінки стану суспільства. Потім, дане визначення почало характеризувати ступінь задоволення потреб у конкретних умовах споживання тієї сукупності властивостей, що явно виражені або потенційно закладені в товар. Ще на початку XX ст., американський аналітик У.Шухарт розробив методику 
статистичного аналізу виробничого процесу та виявлення браку на виробництві, які згодом були названі карти Шухарта [Шендеровський,1976: с. 597].

Пізніше, найбільш відомим як засновник теорії якості став Е. Демінг. Він зробив величезний вплив на відродження післявоєнної Японії і США у 80-х роках. Демінг був першим з тих, кого тепер називають «американськими гуру якості», що відвідали Японію. Його методи статистичного контролю якості були швидко і 3 ентузіазмом сприйняли японськими інженерами, особливо на рівні виробничих підприємств. Їх застосування, стимульовані добре організованою інформацією успішних практичних результатах, швидко поширювалася [Демінг, 2011: с. 68-82.] У 1948 р. у складі Союзу японських учених і інженерів (Union of Japanese Scientists and Engineer - JUSE) була організована Дослідницька група 3 контролю якості (Quality Control Research Group). Робота Е. Демінга в Японії наприкінці 40-50-х років зумовила просування Японії на шлях лідерства в міжнародному виробництві та бізнесі. Подальша робота Демінга і його сподвижників у Сполучених Штатах та інших країнах була спробою змінити стиль західного менеджменту. Багато ідей та пропозицій щодо запровадження та розвитку TQM увійшли в книгу «Out of Crisis», вперше опубліковану в 1982 р. видавництвом «Cambridge University Press». Демінг постійно покращує і шліфує свої ідеї, творчо сприймає ідеї інших, а тому дуже важко чітко виділити власне його концепції. Можливо, доцільніше було б розглядати його діяльність на концептуальному рівні як батька сучасної революції якості наставника номер один. Не випадково журнал «Америка» назвав його «революціонером капіталізму». Зокрема, говорячи про необхідність трансформації американського менеджменту в 80-і роки, він стверджує: «Нездатність менеджменту планувати на майбутнє і передбачати проблеми породила зростання трудомісткості, втрати матеріалів і машинного часу, все це збільшило витрати виробника і ціну, яку покупець повинен платити. Споживач не завжди бажає відшкодовувати ці втрати. Неминучим результатом є втрата ринку». Який же вихід для менеджменту? «Кожному робити все, на що він здатний, - не відповідь. Спочатку необхідно, щоб люди знали, що робити. Потрібні глибокі зміни. Перший крок у перетворенні - це навчитися, як змінювати. Довгострокова прихильність пізнання нового i нової філософії потрібно від будь-якого менеджера, який прагне до перетворення. Боязкі та легкодухі люди, які чекають швидких результатів, приречені на розчарування» [Економічна енииклопедія, 2002: с. 283].

Е. Демінг розглядає свої 14 ключових принципів-заповідей як основу перетворення американської промисловості. Вони ж були основою уроків для вищого японського менеджменту в 1950 р. Демінг підкреслює, що прийняття цих 14 заповідей i дії щодо їх здійснення говорять про те, що менеджмент має намір залишатися в бізнесі і ставить метою захистити інвестора і зберегти робочі місця. Ці заповіді доречні як малим підприємствам, так і великим; як у сфері обслуговування, виробництва, так і в освіті [Демінг, 20011: с. 68-82]. Вони доречні до будь-якого підрозділу в будь-якого підприємства:

1) сталість мети - поліпшення продукції та обслуговування;

2) нова філософія для нового економічного періоду шляхом пізнання менеджерами своїх обов'язків і прийняття на себе лідерства на шляху до змін.

Е. Демінг пропонує план дій, що складається 3 семи пунктів, починаючи 3 освоєння менеджментом кожного 3 пунктів i боротьби зі «смертельними хворобами», якими піддана більшість компаній у західному світі: 
1) керівництво бореться 3 «смертельними хворобами» i перешкодами, погоджує поняття та напрямки планів;

2) керівництво збирається 3 духом і внутрішньо налаштовується на рух в новому напрямку;

3) керівництво пояснює співробітникам компанії, чому зміни необхідні;

4) вся діяльність компанії розбивається на етапи (стадії), при цьому кожен наступний етап є як би замовником попереднього. Постійне поліпшення методів роботи повинно здійснюватися на кожному етапі, і кожен етап повинен працювати в напрямку якості;

5) як можна швидше будується організаційна структура, яка буде працювати на постійне поліпшення якості;

6) кожен співробітник може взяти участь у вдосконаленні роботи на будьякому етапі;

7) будується система якості (Демінг вважає, що для цього потрібна участь досвідчених статистиків) [Демінг, 2011: с. 423-424].

До найбільш цінних досягненням Е. Демінга слід віднести теорію глибинних знань, що включає теорії: систем, варіабельності (мінливості), психології і пізнання.

Глибинні знання демонструють системний підхід до менеджменту якості, що враховує варіабельність (статистичний характер) всіх процесів, а також здібностей людей, їх поведінкові особливості, у тому числі прагнення до досягнення результатів, отримання визнання і радості від роботи. Дуже важлива роль теорії знань (пізнання) для розуміння концепцій безперервного поліпшення, яка була протиставлена панівної ідеї оптимальної якості, тобто того рівня якості, покращувати який невигідно. Така точка зору передбачала обмеженість ресурсів і не враховувала, що отримання нових знань істотно розширює можливості пошуку нових рішень. Нові знання постійно змінюють уявлення щодо оптимального рівня якості і направляють його в бік інтересів споживача.

Не менш відомий, ніж Е. Демінг, американський фахівець в області якості, Джозеф М. Джуран - академік Міжнародної академії якості (МАК). У 1951 р. у США вийшла його книжка «Довідник по управлінню якістю» (Handbook for Quality Control), від якої веде свій початок поняття «керування якістю». У 1964 р. була видана відома книга Джурана «Революція в управлінні підприємством» [Вікторов, 2004: с. 208-214].

Дж. Джуран першим обгрунтував перехід від контролю якості до управління якістю. Їм розроблена знаменита «спіраль якості» (спіраль Джурана) - позачасова просторова модель, яка визначила основні стадії безперервних робіт з управління якістю і послужила прообразом багатьох що з'явилися пізніше моделей.

Дж. Джуран $є$ автором концепції AQI (Annual Quality Improvement) концепції щорічного поліпшення якості. Поліпшення якості, вважає Джуран - це перевищення вже досягнутих результатів роботи в області якості, пов'язане 3 прагненням людини встановити новий рекорд. У філософії менеджменту безперервне поліпшення передбачає, що на зміну політиці стабільності приходить політика змін.

Головна увага в концепції AQI зосереджується на стратегічних рішеннях, більш високої конкурентоспроможності і довгострокових результати. Для реалізації концепції AQI на підприємстві розробляється комплекс заходів, що передбачає:

- складання щорічної програми поліпшення якості;

- розробку методів поліпшення якості його вимірювання і оцінки; 
- навчання статистичних методів і їх впровадження в практику;

- вдосконалення організації робіт в адміністративній сфері. якості.

Дж. Джураном сформульовані основи економічного підходу до забезпечення

Каору Ісікава (Kaom Ishikava - 1915-1990рр.) - видатний японський фахівець в області якості. Діяльність Ісікави невіддільна від історії управління якістю в Японії. Він, автор японського варіанту комплексного управління якістю, найбільш характерними його особливостями є: загальне участь працівників в управлінні якістю; введення внутрішніх регулярних перевірок функціонування системи якості; безперервне навчання кадрів; широке впровадження статистичних методів контролю [Економічна енииклопедія, 2002: с. 285].

Геніті Тагуті (Genichi Taguchi, нар. в 1924 р.) - відомий японський статистик, розвинув ідеї математичної статистики планування експерименту і контролю якості [Егорииин, 2002: с. 68-82].

Головне у філософії Тагуті - це підвищення якості з одночасним зниженням витрат. Згідно Тагуті, економічний фактор (вартість) та якість аналізуються спільно. Обидва фактори пов'язані загальною характеристикою, званої функцією втрат. При аналізі розглядаються втрати як з боку споживача, так і з боку виробника. Методи Тагуті дозволяють проектувати вироби і процеси, не чутливі до впливу так званих «шумів», тобто змінних факторів, що викликають розкид значень параметрів, які важко, неможливо або дорого змінити. Таку стійкість прийнято називати робастністю (від англ. robust - міцний, стійкий). Тагуті акцентує увагу на етапах, що передують проектування вироби, оскільки саме на них вирішується завдання досягнення робастності [Егоришин, 2002: c. 68-82]. Заслуга Тагуті полягає в тому, що він зумів знайти порівняно прості і переконливі аргументи і прийоми, які зробили планування експерименту в області забезпечення якості реальністю. Саме в цьому бачить сам Тагуті головну особливість свого підходу.

Як бачимо, серед засновників немає європейців. Це викликає певну i зрозумілу стурбованість європейських фахівців. Зокрема, проф. Тоні Бенделл 3 Великобританії відзначає, що більшість гуру з США, а ті концепції якості, які мають японське походження, також потрапили в Європу через США. Однак з точки зору споживача, європейська концепція якості означає щось більше, ніж американське відповідність призначенням. Згідно 3 необхідністю дотримуватись умови відповідності, сфера обслуговування відтворює ідентичні ресторани (поширена у світі мережа швидкого харчування Макдональд), готелі (наприклад Хілтон), яким бракує стилю і характеру. У виробничому секторі традиційна європейська концепція якості також включає гарний естетичний дизайн і хороший інженерний задум поряд 3 необхідною функціональністю. Таким чином, концепція якості для Сполученого Королівства та Європи - це щось більше, ніж просто адекватне повторення того, що існує в американських теоріях. Цю концепцію необхідно розвивати, або британської промисловості доведеться конкурувати і на своєму, і на європейському ринках в «американських умовах», певною мірою неприйнятних для Великобританії [Економічна енииклопедія, 2002: с. 281].

Бове і Тілл дають таке визначення підходу TQM: «Загальне керування якістю - це філософія організації, яка заснована на прагненні до якості і практиці управління, яка призводить до загального якості, звідси якість - це не те, що вам доводиться відслідковувати або додавати на якомусь етапі виробничого процесу, це сама сутність організації». Більшою мірою підходи ТQМ викладені в МС ИСО 
9004:2000, що містить мінімум вимог для задоволення запитів споживачів. Головна відмінність полягає в тому, що ТQМ є вершиною сучасних методів управління якістю та орієнтована на підвищення якості виробів, коли вже є якийсь досягнутий рівень, а впровадження стандартів ICO серії 9000 швидше спрямоване на зниження ймовірності зробити щось невірно [Ярмаченко, 1996: с. 15-19].

TQM перенесений в освіту, отримав назву Total Quality Education (TQE). Метою застосування TQE $є$ досягнення більш високої якості освіти. TQE-це «орієнтована на студента навчальна філософія безперервного поліпшення якості», «процес, який фокусується на задоволенні вимог i очікувань замовника, безперервного поліпшення, розподіл відповідальності зі службовцями і виключення витрат з переробок». TQE припускає наявність і розвиток демократичних відносин між учасниками освітнього процесу.

TQE - це стратегічно інтегрований підхід, спрямований на покращення всіх компонентів навчального процесу ,починаючи від вступної компанії, формування контингенту, аналізу, затвердження та постійного вдосконалення освітньопрофесійних програм, практичної підготовки, надання кваліфікації та розподілу випускників. В управлінні якістю, на основі TQE, визначальними для сучасної системи вищої освіти є десять факторів:

1) Безпосередня зацікавленість у результатах та участь вищого керівництва.

2) Стратегічне планування, визначення перспективних потреб на випускників, вимог до ОКХ.

3) Організація навчального процесу націлена на якість.

4) Залучення до розробки системи всіх працівників, командна робота.

5) Систематична налагоджена система навчання якості всіх працівників.

6) Комплексна система управління на основі широкого впровадження IT.

7) Дієвий контроль навчального процесу, документообігу, інфраструктури.

8) Належне ресурсне забезпечення.

9) Інформація та аналіз.

10) Орієнтація навчального процесу на запити споживачів [Національне акредитаційне агентство...].

Виходячи 3 філософії управління якістю на основі TQM формулюється стратегія і політика, які описують фундаментальні цілі і завдання керівництва освітньої установи. Стратегія визначає, яким чином має розвиватися потенціал вищого і як він повинен використовуватися для досягнення поставлених цілей. Оперативні цілі формуються керівництвом на основі визначеної політики і стратегії вищого навчального закладу. Вони конкретизують поставлені цілі і служать для визначення дій по їх реалізації. Таким чином, філософія управління на основі TQE визначає політику і цілі керівництва. Вона задає показники для розробки системи управління та системи виконання рішень.

Європейською асоціацією по забезпеченню якості вищої освіти ENQA (European Network for Quality Assurance), згідно наказів Конференції міністрівучасників Болонського процесу, сформульовані наступні визначення «Стандартів і рекомендацій по забезпеченню якості вищої освіти в Свропейському просторі» ESG - European Standards and Guidelines:

1) визначити загальну структуру систем якості освіти i навчання на загальноєвропейському, національному та інституціональному рівнях;

2) підтримувати розвиток гарантії і удосконалення якості вищої освіти в європейському освітньому просторі; 
3) підтримувати взаємну довіру,i, таким чином, підтримувати визнання i мобільність в рамках національних кордонів;

4) підтримувати взаємну довіру, i, таким чином, визнавати мобільність в рамках державних кордонів;

5) надавати інформацію по забезпеченню якості освіти в європейському просторі вищої освіти.

Принципи забезпечення якості за міжнародними стандартами ESQ ENQA:

1) ЗВО несуть відповідальність за якість наданої освіти і забезпечення ії надання;

2) забезпечення якості відповідає потребам різних систем вищої освіти, вузів і студентів;

3) забезпечення якості вищої освіти підтримує розвиток культури якості;

4) система забезпечення якості вищої освіти бере до уваги потреби i очікування студентів та інших зацікавлених у процесі навчання сторін [Жовта,2003: c. 22-30].

Г. Клімова, в своїй статті «Якість вищої освіти: Європейський вимір» визначає, що поняття «якість» носить багатоаспектний характер у залежності від об'єкта і галузі, які розглядаються. Стосовно вищої освіти воно має різні значення у залежності від вимог сторін, які зацікавлені в діяльності вузу: держави, роботодавців, студентів, професорсько-викладацького складу, від якості тієї академічної галузі, яку треба оцінити, а також, від історичного періоду в розвитку вищої світи тощо [Клімова, 2016: c. 204].

У межах проекту UNESCO-CEPES «Стратегічні показники вищої освіти в XXI столітті» відображені такі основні підходи до визначення якості вищої освіти:

1) Якість вищої освіти, як зверхність (високий рівень складності програми, процедур тестування студентів, імідж ВНЗ не тільки на національному, але й на міжнародному рівні).

2) Якість, як відповідність поставленим цілям (відповідність загальноприйнятим стандартам, визначеним акредитаційним органом, 3 акцентом на досягнуті результати освітнього процесу або навчальної програми).

3) Якість, як задоволення споживача (виправдання очікувань споживачів: студентів, батьків, суспільства в цілому та інших зацікавлених сторін).

4) Якість, як синонім покращення (процес, спрямований на постійне вдосконалення, розвиток відповідальності вищого навчального закладу за краще використання його інституційної автономії та свободи) [Національне акредитаційне агентство...].

Висновки. Отже, кожен із наведених підходів має свої переваги й обмеження в залежності від певного етапу розвитку вищої освіти, національної специфіки сприйняття, також вимог, що висуваються ринком праці. Але, пріоритет розвитку підвищення показників в освіті залишається за об'єднанням та ефективним використанням людського потенціалу, комп'ютерних технологій і інформаційних ресурсів, задля здійснення функцій контролю та управління процесами на різних організаційних рівнях. Ефективність функціонування всіх підсистем в значній мірі залежить від культури, а також всіх існуючих переконань: правил і традицій, що забезпечують єдність установи та його пристосованість до зовнішнього оточення. Подальше дослідження зазначеної наукової проблеми вимагає розкриття таких аспектів, як аналіз методів контролю якості, вивчення системно-запроваджених та планомірно-організованих робіт по забезпеченню якості у всіх ланках вищої освіти, 


\section{зв'язок особистого внеску із загальними результатами, вдосконалення системи менеджменту якості в цілому.}

\section{ЛІТЕРАТУРА}

Вікторов, 2004 - Вікторов В. Г. Якість освіти: основні наукові підходи та уявлення / В Г. Вікторов // Актуальні філософ. та культурол. пробл. сучасності: Альманах. - К., 2004. - Вип. 14. - С. $208-214$.

Демінг, 2011 - Деминг Эдвардс. Выход из кризиса: Новая парадигма управления людьми, системами и процессами//М.: Альпина Паблишер, 2011. - 424 с.

Єгоришин, 2002 - Єгоршин А.П., Пряничніков С.Б. Методологія оцінки якості і ефективності вищої освіти // Школ.технології. - 2002. - №5. - С. 68-87.

Економічна енциклопедія, 2002 - Економічна енциклопедія: У трьох томах. Т. 3. / Редкол.: ...С. В. Мочерний (відп. ред.) та ін//. - К.: Видавничий центр «Академія», 2002. - с. 281.

Жовта, 2003 - Жовта I. Якість науково-педагогічних кадрів вищої школи України / Ірина Жовта // Вища шк. - 2003. - № 4/5. - С. 22-30.

Клімова, 2016 - Клімова Г. П. Якість вищої освіти: Європейський вимір/Клімова Г.П,// 2016- 204 Вісник Національного університету «Юридична академія України імені Ярослава Мудрого». - № 1 (28). 2016.

Національне акредитаційне... - Національне акредитаційне агентство в сфері освіти /Електронний ресурс // Режим доступу: www.nica.ru/ru/about/internationalactivity/enqa.

Шиндеровський, 1976 - Шиндовский Э. Статистические методы управления качеством: Контрольные карты и планы контроля / Шиндовский, О. Шюрц//. - М. : Мир, 1976. - 597 с.

Ярмаченко, 1996 - Ярмаченко М.Д. Деякі методологічні питання управління системою освіти в Україні // Шлях освіти. - 1996. - №1. - С.15-19.

\section{REFERENCES}

Viktorov, 2004 - Viktorov V. H. Yakist osvity: osnovni naukovi pidkhody ta uiavlennia / V H. Viktorov // Aktualni filosof. ta kulturol. probl. suchasnosti: Almanakh. - K., 2004. - Vyp. 14. - S. 208-214.

Deminh, 2011 - Demynh Edvards. Vykhod yz kryzysa: Novaia paradyhma upravlenyia liudmy, systemamy y protsessamy//M.: Alpyna Pablysher, 2011. - 424 s.

Yehoryshyn, 2002 - Yehorshyn A.P., Prianychnikov S.B. Metodolohiia otsinky yakosti i efektyvnosti vyshchoi osvity // Shkol.tekhnolohii. - 2002. - №5. - S. 68-87.

Ekonomichna entsyklopediia, 2002 - Ekonomichna entsyklopediia: U trokh tomakh. T. 3. / Redkol.: ... S. V. Mochernyi (vidp. red.) ta in//. - K.: Vydavnychyi tsentr «Akademiia», 2002. - s. 281.

Zhovta, 2003 - Zhovta I. Yakist naukovo-pedahohichnykh kadriv vyshchoi shkoly Ukrainy / Iryna Zhovta // Vyshcha shk. - 2003. - № 4/5. - S. 22-30.

Klimova, 2016 - Klimova H. P. Yakist vyshchoi osvity: Yevropeiskyi vymir/Klimova H.P. // 2016- 204 Visnyk Natsionalnoho universytetu «Iurydychna akademiia Ukrainy imeni Yaroslava Mudroho». - № 1 (28). 2016.

Natsionalne akredytatsiine... - Natsionalne akredytatsiine ahentstvo v sferi osvity /Elektronnyi resurs // Rezhym dostupu: www.nica.ru/ru/about/internationalactivity/enqa.

Shynderovskyi, 1976 - Shyndovskyi E. Statystycheskye metody upravlenyia kachestvom: Kontrolnye karty y plany kontrolia / Shyndovskyi, O. Shiurts//. - M. : Myr, 1976. - 597 s.

Yarmachenko, 1996 - Yarmachenko M.D. Deiaki metodolohichni pytannia upravlinnia systemoiu osvity v Ukraini // Shliakh osvity. - 1996. - №1. - S.15-19. 